\title{
PEMANFAATAN LIMBAH BATUBARA (FLY ASH) SEBAGAI MATERIAL PENGGANTI AGREGAT KASAR PADA PEMBUATAN BETON RINGAN
}

\author{
Ani Firda*, Rosmalinda Permatasari, Indra Syahrul Fuad \\ Jurusan Teknik Sipil, Fakultas Teknik, Universitas Tridinanti Palembang \\ *Corresponding Author, email : ani.firda@gmail.com
}

\begin{abstract}
ABSTRAK
Sebagai salah satu bahan bangunan perkembangan beton beton saat begitu pesat, yang merupakan campuran pasir dan kerikilyang ditambah semen dan air. Beton ringan adalah beton yang memiliki berat jenis (density) maksimum sebesar $1.850 \mathrm{~kg} / \mathrm{m} 3$. Pada proyek bangunan tinggi (high rise building) penggunaan beton ringan secara signifikan dapat mengurangi berat konstruksi. Beton ringan dapat dibuat dengan dengan mengganti agregat kasar maupun agregat halus dengan material yang berat jenisnya lebih ringan. Dalam penelitian ini, penulis menggunaan fly ash sebagai material pengganti aggregat kasar pembentuk beton. Fly ash yang merupakan limbah batubara akan dicampur dengan bahan kimia resin yang berfungsi sebagai pengikat dan perekat dengan perbandingan komposisi agregat $60 \%$ fly ash dan resin $40 \%$. Hasil pengujian analisa saringan yang dilakukan terhadap agregat kasar buatan tersebut didapat gradasi agregat kasar adalah jenis kerikil atau koral untuk ukuran maksimum $20 \mathrm{~mm}$ dan berat jenisnya adalah $1891 \mathrm{~kg} / \mathrm{m} 3$ dengan kuat tekan betonnya pada umur 28 hari sebesar 6,85 Mpa. atau mengalami penurunan dari beton normal sebesar 10,92 Mpa (38,55\%). Sehingga disimpulkan bahwa beton dengan campuran agregat fly ash 60\% dan resin 40\% ini belum dapat digunakan sebagai beton ringan struktural karena hasil kuat tekannya yang rendah dibanding dengan beton normal, sehingga hanya dapat digunakan untuk beton ringan non struktural.
\end{abstract}

Kata Kunci : Aggregat kasar buatan, Fly ash, Resin, Beton ringan

\begin{abstract}
As one of the building materials for the rapid development of concrete, which is a mixture of sand and gravel, added with cement and water. Lightweight concrete is concrete that has a maximum density of 1,850 $\mathrm{kg} / \mathrm{m} 3$. In high rise building projects, the use of lightweight concrete can significantly reduce the weight of the construction. Lightweight concrete can be made by replacing coarse aggregate or fine aggregate with a material that is lighter in density. In this study, the authors used fly ash as a substitute material for coarse aggregates to form concrete. Fly ash which is coal waste will be mixed with chemical resin which functions as a binder and adhesive with an aggregate composition ratio of $60 \%$ fly ash and $40 \%$ resin. The results of the sieve analysis test carried out on the artificial coarse aggregate obtained that the coarse aggregate gradation is a type of gravel or coral for a maximum size of $20 \mathrm{~mm}$ and its specific gravity is $1891 \mathrm{~kg} / \mathrm{m} 3$ with a concrete compressive strength at 28 days of $6.85 \mathrm{MPa}$. or decreased from normal concrete of 10.92 $\mathrm{MPa}(38.55 \%)$. So it can be concluded that concrete with a mixture of $60 \%$ fly ash aggregate and $40 \%$ resin cannot be used as structural lightweight concrete because of its low compressive strength compared to normal concrete, so it can only be used for non-structural lightweight concrete
\end{abstract}

Keywords : Artificial coarse aggregate Fly ash, Resin, Lightweight concrete

\section{PENDAHULUAN}

Sebagai salah satu bahan bangunan perkembangan beton beton saat begitu pesat, yang merupakan campuran pasir dan kerikilyang ditambah semen dan air. Sebagai salah satu komponen dalam konstruksi, beton dalam penggunaannya perlu penanganan dan pengawasan secara cermat, dimana mutu beton yang baik tergantung dari bahan-bahan penyusunnya. Dan hal ini menjadikan beton sebagai salah satu bahan alternatif untuk 
dikembangkan dari metode pelaksanaan maupun pembuatannya.

Keunggulan beton sangat banyak yaitu kuat tekan betonnya tinggi, tahan terhadap api dibandingkan material baja, struktur yang dibentuk sangat kaku, umur layan yang panjang dan biaya perawatan rendah, dapat dibentuk dalam berbagai penampang, kebutuhan tenaga kerja terampil berkualifikasi tinggi tidak banyak dibutuhkan. Beton juga mempunyai kelemahan yaitu (1) kuat tariknya yang rendah, (2) untuk menjadi suatu struktur, material pembuatan beton harus dicampur, dicetak dan dirawat supaya mencapai kuat tekan yang diinginkan, (3) biaya cetakan betonnya cukup tinggi, (4) berpotensi adanya retakan pada beton dikarenakan adanya susut beton dan beban hidup yang bekerja, (5) mutu beton yang dihasilkan tergantung dari proses pencampuran sampai proses pencetakan beton. (Purwanto, H ; 2020)

Dalam SNI 2847:2013, kategori beton ringan (lightweight concrete) merupakan beton dengan agregat dan berat volume yang setimbang (equilibrium density), yaitu 1140-1840 $\mathrm{kg} / \mathrm{m} 3$ (ASTM C567). Dan untuk mendapatkan berat isi beton yang ringan, salah satu metodenya dengan dengan melakukan standarisasi yang sesuai, dimana agregat ringan berfungsi sebagai agregat kasar pada beton. Menurut standar SNI 03-2461-2002, agregat ringan terdiri dari 2 jenis : (1) agregat ringan yang dibuat dari proses pemanasan sintering (bahan terak tanur tinggi), lempung (clay), diatome, abu terbang (fly ash), batu sabak, dan batu obsidian (2) agregat ringan yang didapat secara alami, seperti batu apung (scoria), batu letusan gunung (batuan lahar). Sedangkan dari ASTM C330-034 dibedakan menjadi dua : (1) Hasil proses sisa produksi (sisa pembakaran tanah liat dan lain-lain), (2) Hasil proses pengolahan bahan alam (batu apung)

Proses pembuatan beton ringan ada tiga cara : (1) Menggunakan bahan air-entraining agent (bahan aditif) sebagai pembuat gelembung udara pada proses pencampuran beton sehingga membuat beton mempunyai rongga dan berat jenisnya mengalami penurunan, (2) agregat diganti dengan material yang berberat jenis lebih ringan, (3) proses pembuatannya tidak memakai (Tjokrodimuljo, 2007).

Fly ash (abu terbang) merupakan abu hasil sisa pembakaran batubara berbutir halus dan bersifat pozzolanik. Fly ash bersifat tidak mampu mengikat beton seperti semen, tetapi dengan campuran air dan partikel berukuran halus, ditambah oksida silica yang ada di dalam fly ash dan melalui proses kimiawi dengan kalsium hidroksida akibat proses hidrasi semen, akan menghasilkan zat dengan kemampuan sebagai pengikat (Krisbiyantoro, 2005 dalam Eko Hindaryanto Nugroho, 2010)

Sebagai material pembentuk beton, jika ditinjau dari segi lingkungan, penggunaan fly ash berdampak positif, tetapi akan berdampak negatif juga, yaitu terjadi pencemaran udara dikarenakan kehalusan butiran fly ash. Dimana, penanganan fly ash saat ini masih terbatas pada daerah lahan kosong.

Berbagai penelitian terkait beton ringan yang menggunakan bahan limbah sebagai agregat ringan buatan sudah dilakukan, diantaranya penelitian yang dilakukan oleh George K George1 and P Revathi2 (2020) yang berjudul Production and Utilisation of Artificial Coarse Aggregate in Concrete - a Review. Penelitian ini melakukan studi tentang berbagai jenis agregat buatan seperti abu terbang, GGBS, abu sekam padi, abu vulkanik, dll. Metode yang dilakukan yaitu membuat agregat dengan molaritas yang berbeda, menggunakan metode umum seperti metode ikatan dingin, autoklaf, dan sintering, 
dibentuk seperti pelet untuk mendapatkan berat jenis yang lebih rendah dari agregat alami. Hasil penelitian menunjukkan bahwa (1) Gravitasi spesifik agregat buatan adalah 30 sampai 50\% lebih kecil dari pada agregat alami yang disukai struktur beton ringan. (2) Penyerapan air pada agregat buatan adalah 2 sampai 5 kali lebih tinggi jika dibandingkan dengan agregat normal. (3) Kekuatan tekan campuran dengan agregat buatan ditemukan hampir 5 - 15\% kurang dari beton konvensional. (4) Daya tahan bervariasi sesuai dengan metode pembuatan agregat buatan dan desain campuran beton.

Penelitian ini, akan mengidentifikasi penggunaan fly ash sebagai material pengganti aggregat kasar pembentuk beton. Dimana Fly ash yang merupakan limbah batubara akan dicampur dengan bahan kimia resin yang berfungsi sebagai pengikat dan perekat fly ash yang akan dibuat sebagai pengganti aggregat kasar. Dan akan di titik beratkan pada pengaruh penggunaan aggregat kasar buatan ini terhadap kuat tekan beton ringan.

\section{METODE PENELITIAN}

Penelitian ini dilakukan di Laboratorium Beton, Fakultas Teknik, Universitas Tridinanti Palembang, mulai April hingga Desember 2020

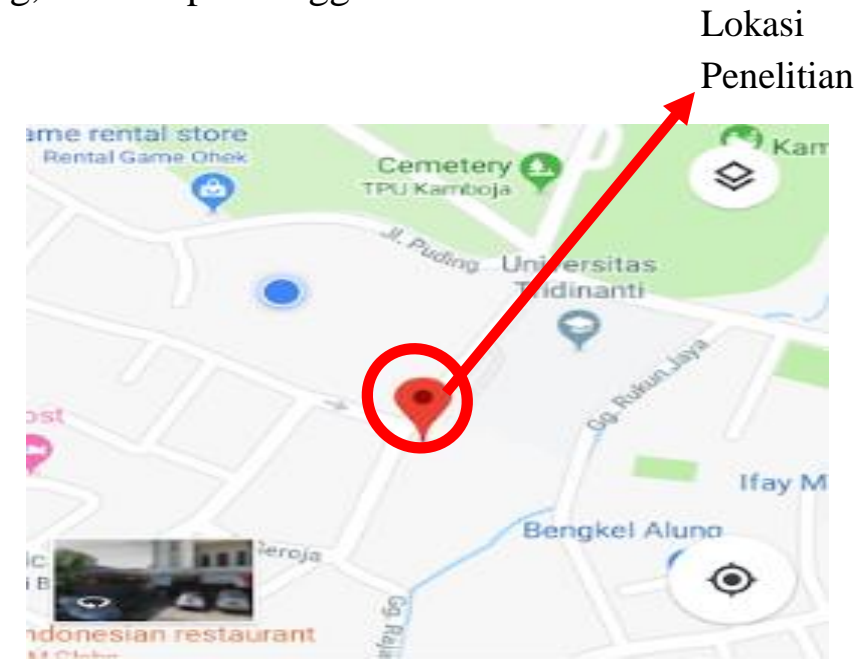

Gambar 1. Lokasi Laboratorium Beton Universitas Tridinanti Palembang

Dalam penelitian ini digunakan data primer dengan cara percobaan benda uji dengan berbagai campuran dan data sekunder berupa literatur dari penelitian sebelumnya maupun buku referensi.

Penelitian ini dimulai dengan membuat agregat ringan yang bahan dasarnya adalah fly ash dan resin, kemudian dilakukan pengujian agregat (kasar dan halus), yaitu pengujian berat jenis, kadar air, berat isi, kadar lumpur, analisa saringan dan keausan agregat. Selanjutnya dibuat job mix design (rancangan campuran beton) dengan mutu fc' $=17,5$ $\mathrm{MPa}$, yang berpedoman pada peraturan SNI 7656-2012. Proses selanjutnya dibuat benda uji menggunakan cetakan silinder $\varnothing 150 \mathrm{~mm}$ dan tinggi $300 \mathrm{~mm}$. Pengujian kuat tekan benda uji dilakukan saat beton berumur 3, 7, 14, 21 dan 28 hari, yang masing-masing umur beton dibuat 3 benda uji. Jumlah sampel benda uji seperti tabel berikut : 
Tabel 1. Jumlah Sampel Kuat Tekan Beton Normal dan Beton Ringan

\begin{tabular}{|c|c|c|c|}
\hline No & Jenis & Usia Beton (hari) & Jumlah Sampel \\
\hline 1 & Beton Normal & & 25 buah \\
\hline 2 & Beton Ringan & $3,7,14,21,28$ & 25 buah \\
\hline \multicolumn{2}{|c|}{ Total } & 50 buah \\
\hline
\end{tabular}

Pada penelitian ini digunakan material : (1) Semen portland komposit (Portland Composite Cement) produk Semen Baturaja, (2) Pasir sebagai ari Tanjung Raja Kab. OKI Sumsel, (3) Agregat kasar buatan (campuran fly ash dan resin) dengan ukuran 19 - 25 mm, (4) Air dari PDAM Tirta Musi Palembang.

Tahapan pembuatan benda uji beton normal : (1) Setelah campuran beton siap, kemudian sebagai lapis pertama dimasukkan ampuran kedalam cetakan silinder sebanyak 1/3 dari volume cetakan, kemudian masing-masing 1/3 bagian untuk lapisan kedua dan ketiga, (2) Pada setiap lapis dipadatkan dengan ditusuk besi pemadat sebanyak 25 kali tusuan, (3) Dan terakhir permukaan atas adukan diratakan

Agregat ringan buatan dibuat dengan tahapan sebagai berikut : (1) Fly ash terlebih dahulu dikeringkan dengan memasukkan ke dalam oven bersuhu $110^{\circ} \mathrm{C}$ selama \pm 1 jam, (2) Kemudian dilakukan penimbangan aggregat dengan menggunakan timbangan digital, (3) Setelah itu dilakukan penimbangan terhadap bahan kimia resin yang akan digunakan. Cairan resin di tambahkan katalis untuk mempercepat proses pengerasan. Campuran antara resin dan katalis adalah 1 liter : 1/40 liter, (4) Proses pencampuran abu terbang (fly ash) dan resin dilakukan dengan perbandingan resin $40 \%$ dari berat abu terbang (fly ash), (5) Proses pembentukan aggregat, aggegat kasar buatan dicetak pada loyang 20x20 cm, kemudian sebelum aggegat tersebut mengeras di lakukan proses pemotongan anggregat menjadi ukuran kecil dengan ukuran $10 \mathrm{~mm}$ sampai $40 \mathrm{~mm}$, (6) Kemudian dilakukan proses pengeringan selama 2 hari sampai aggrerat ringan bisa digunakan sebagai campuran beton.

Sebelum benda uji dibuat, maka harus dilakukan slump test terlebih dahulu. Setelah 24 jam, benda uji dibuka dari cetakannya, dan benda uji diselimuti karung goni serta disiram dengan waktu tertentu. Selanjutnya benda uji direndam di dalam air dengan $\mathrm{pH}$ normal sampai satu hari sebelum benda diuji.

\section{HASIL DAN PEMBAHASAN}

Agregat pengganti yang dibuat berbahan dasar abu terbang (fly ash) dan resin. Rasio perbandingan antara abu terbang dan resin yaitu $60: 40$, atau jumlah pemakaian resin sebesar $40 \%$ dari jumlah abu terbang (fly ash) yang digunakan. Pengujian yang dilakukan antara lain adalah pengujian agregat halus dan kasar, meliputi percobaan berat jenis agregat (SSD), berat isi agregat, analisa saringan agregat halus dan kasar, abrasi (keausan) agregat dan kadar lumpur agregat.

Setelah dilakukan pengujian agregat kasar dan halus barulah didapat persentase jumlah agregat halus, agregat kasar, semen, air dan agregat buatan yang akan digunakan untuk pembuatan benda uji berbentuk silinder $\varnothing 150 \mathrm{~mm}$ x $300 \mathrm{~mm}$. Berdasarkan ketentuan SNI, lalu dilakukan perencanaan perhitungan campuran beton menurut SNI 03- 
2834-2000 sesuai mutu beton yang direncanakan yaitu fc' 17,5 Mpa. Setelah itu pembuatan benda uji selesai dilakukan, maka dilakukan perawatan benda uji yaiitu dengan merendamnya di dalam air, barulah setelah itu bisa dilakukan pengujian kuat tekan beton.

Uji slump (slump test) dilakukan untuk mengukur kekentalan suatu adukan beton yang ditunjukkan pada tabel berikut :.

Tabel 2. Hasil Pengujian Slump Beton

\begin{tabular}{|c|c|c|c|c|}
\hline No & $\begin{array}{c}\text { Varian } \\
\text { Campuran }\end{array}$ & $\begin{array}{l}\text { Jumlah } \\
\text { adukan }\end{array}$ & $\begin{array}{c}\text { Hasil Slump } \\
\text { test }\end{array}$ & $\begin{array}{l}\text { Nilai Rata-rata } \\
(\mathrm{cm})\end{array}$ \\
\hline \multirow{5}{*}{1} & \multirow{5}{*}{ Beton normal } & 1 & 10,5 & \multirow{5}{*}{11,9} \\
\hline & & 2 & 12 & \\
\hline & & 3 & 13 & \\
\hline & & 4 & 12 & \\
\hline & & 5 & 12 & \\
\hline \multirow{5}{*}{2} & \multirow{5}{*}{ Beton Ringan } & 6 & 7,5 & \multirow{5}{*}{9,2} \\
\hline & & 7 & 10 & \\
\hline & & 8 & 10,5 & \\
\hline & & 9 & 8 & \\
\hline & & 10 & 10 & \\
\hline
\end{tabular}

Pada tabel 2 diatas, pada beton normal, didapat slump sebesar $11,9 \mathrm{~cm}$ sedangkan beton ringan $9,2 \mathrm{~cm}$.

Pengujian kuat tekan beton normal ditujukkan hasilnya seperti tabel berikut :

Tabel 3. Hasil Kuat Tekan Beton Normal

\begin{tabular}{|c|c|c|c|c|c|c|c|}
\hline \multirow{3}{*}{ No } & \multirow{2}{*}{$\begin{array}{c}\text { Jenis } \\
\text { Beton }\end{array}$} & \multirow{2}{*}{$\begin{array}{c}\text { Nomor } \\
\text { Sampel }\end{array}$} & \multicolumn{5}{|c|}{ Kuat Tekan Rata-rata (Mpa) } \\
\cline { 4 - 8 } & & 3 & 7 & 14 & 21 & 28 \\
\hline \multirow{3}{*}{1} & \multirow{3}{*}{\begin{tabular}{c} 
Beton \\
\cline { 3 - 7 }
\end{tabular}} & 1 & 6,22 & 11,03 & 16,40 & 16,40 & 17,27 \\
\cline { 3 - 7 } & Normal & 2 & 5,66 & 11,31 & 14,71 & 16,97 & 17,86 \\
\cline { 3 - 8 } & 3 & 5,66 & 11,88 & 15,84 & 17,25 & 18,16 \\
\hline \multicolumn{2}{|c|}{ Rata-Rata } & 5,85 & 11,41 & 15,65 & 16,88 & 17,76 \\
\hline
\end{tabular}

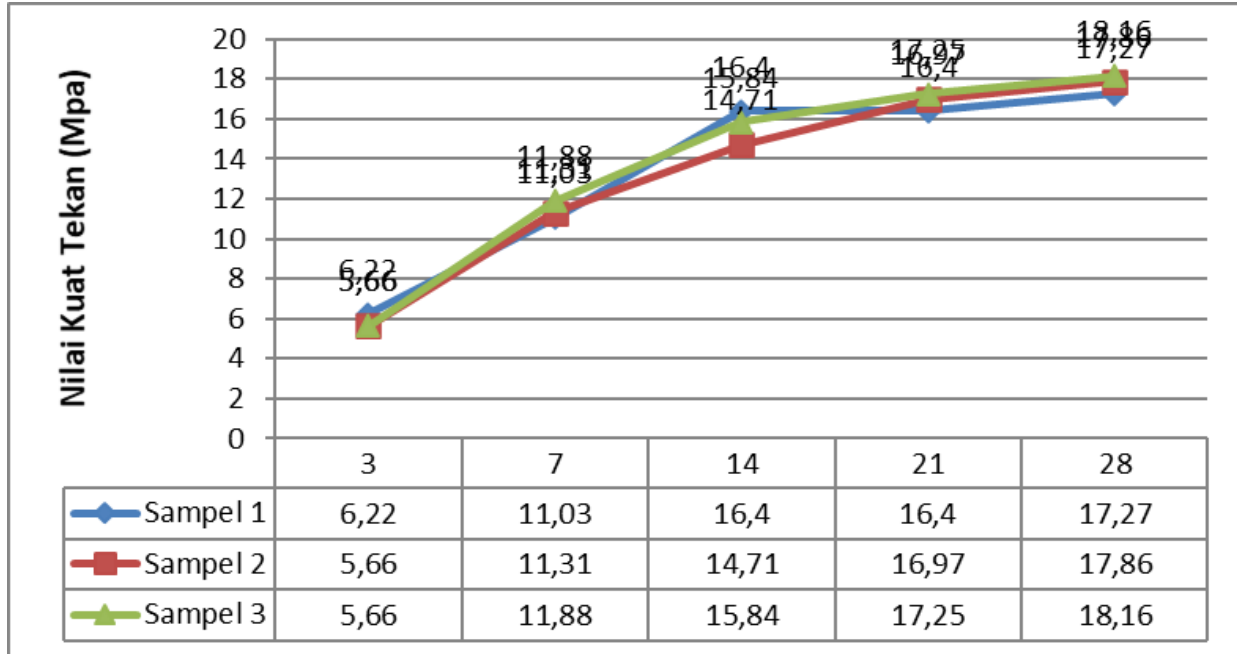

Gambar 2. Diagram Hasil Uji Kuat Tekan Beton Normal 
Hasil pengujian kuat tekan beton ringan ditujukkan seperti tabel berikut :

Tabel 4. Kuat Tekan Beton Ringan

\begin{tabular}{|c|c|c|c|c|c|c|c|}
\hline \multirow{3}{*}{ No } & \multirow{3}{*}{$\begin{array}{c}\text { Jenis } \\
\text { Beton }\end{array}$} & \multirow{2}{*}{$\begin{array}{c}\text { Nomor } \\
\text { Sampel }\end{array}$} & \multicolumn{5}{|c|}{ Kuat Tekan Rata-rata (Mpa) } \\
\cline { 4 - 8 } & & 3 & 7 & 14 & 21 & 28 \\
\hline \multirow{3}{*}{1} & \multirow{2}{*}{$\begin{array}{c}\text { Beton } \\
\text { Ringan }\end{array}$} & 2 & 2,55 & 4,24 & 4,53 & 6,22 & 6,55 \\
\cline { 4 - 8 } & & 2,26 & 4,53 & 5,66 & 6,79 & 7,15 \\
\cline { 4 - 8 } & & 2,26 & 3,96 & 5,37 & 6,51 & 7,07 \\
\hline \multicolumn{2}{|c|}{ Rata-Rata } & 2,36 & 4,24 & 5,19 & 6,51 & 6,85 \\
\hline
\end{tabular}

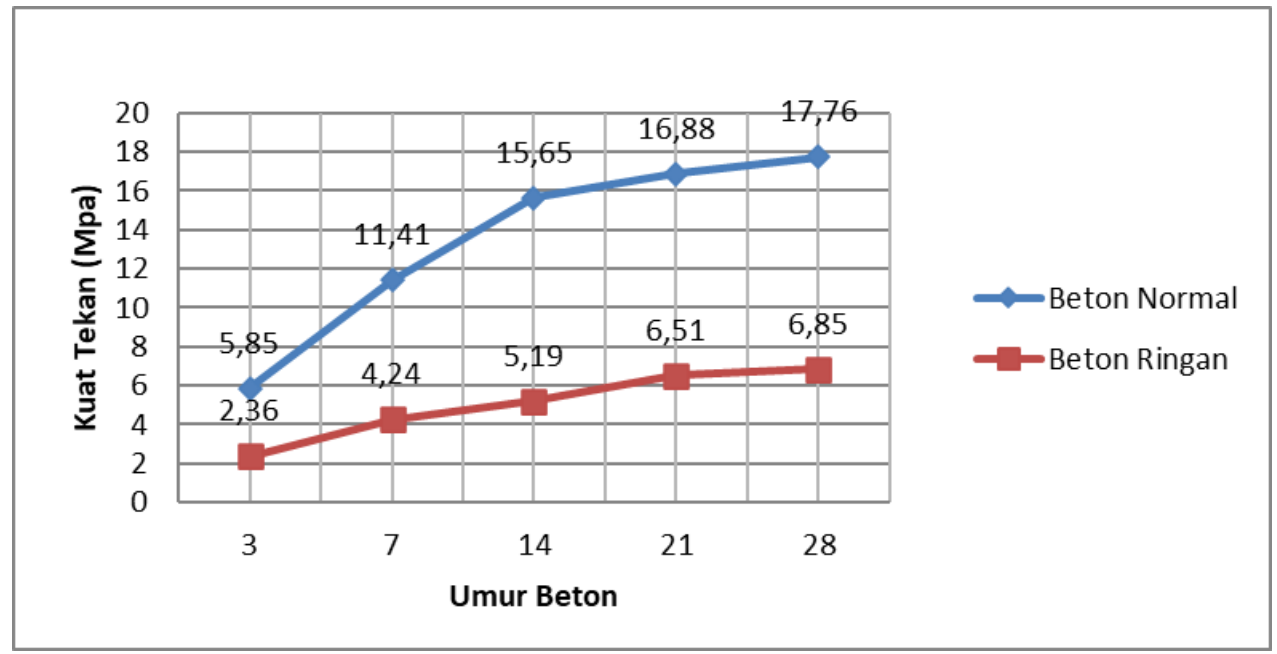

Gambar 3. Diagram Hasil Uji Kuat Tekan Beton Ringan

Perbandingan hasil pengujian kuat tekan beton normal dan beton ringan seperti gambar berikut :

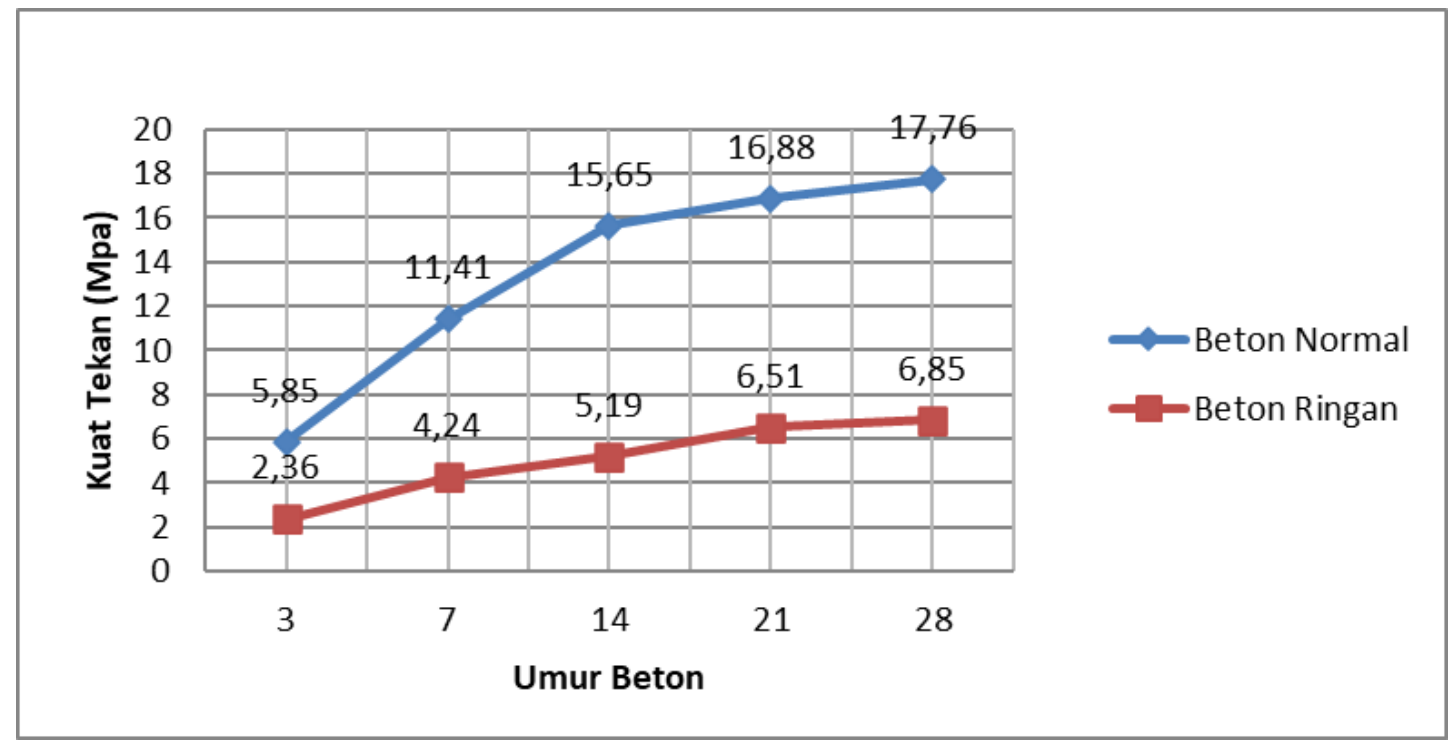

Gambar 4. Perbandingan Rata-rata Kuat Tekan Antara Beton Ringan dan Beton Normal 
Pada umur 28 hari, kuat tekan beton normal didapat nilai 17,76 Mpa, lebih besar dari perencanaan mutu beton $17,5 \mathrm{Mpa}$, yang berarti beton normal memenuhi persyaratan. Beton dengan menggunakan agregat pengganti abu terbang (fly ash) dan $40 \%$ resin umur 28 hari mendapatkan hasil uji kuat tekan 6,85 Mpa mengalami penurunan sebesar 10,92 Mpa dari pada beton normal umur 28 hari atau sekitar 38,55\%. Pada umur 21 hari, kuat tekan beton normal didapat nilai $16,88 \mathrm{Mpa}$, sedangkan beton ringan dengan agregat pengganti fly ash dan 40\% resin medapatkan kuat tekan sebesar 6,51 Mpa mengalami penurunan sebesar 10,37 Mpa atau sekitar 38,55\%. Pada umur 14 hari, kuat tekan beton normal didapat nilai 15,65 Mpa, sedangkan beton ringan dengan agregat pengganti fly ash dan 40\% resin medapatkan kuat tekan sebesar 5,19 Mpa mengalami penurunan sebesar 10,46 Mpa atau sekitar 33,13\%. Pada umur 7 hari, kuat tekan beton normal didapat nilai 11,41 Mpa, sedangkan beton ringan dengan agregat pengganti fly ash dan resin $40 \%$ medapatkan kuat tekan sebesar 4,24 Mpa mengalami penurunan sebesar 7,16 Mpa atau sekitar 37,19\%. Pada umur 3 hari, kuat tekan beton normal didapat nilai 5,85 Mpa, sedangkan beton ringan dengan agregat pengganti fly ash dan $40 \%$ resin medapatkan kuat tekan sebesar 2,36 Mpa mengalami penurunan sebesar 3,49 Mpa atau sekitar 40,32\%. Pengujian antara beton normal dan beton ringan dengan agregat pengganti fly ash dan $40 \%$ resin, maka didapat nilai rata-rata penurunan kuat tekan beton yaitu sebesar 8,48 Mpa dengan persentase rata-rata penurunan sebesar $37,55 \%$.

\section{KESIMPULAN}

Dari hasil penelitian yang dilakukan, fly ash yang merupakan limbah batu bara dapat dimanfaatkan sebagai material pengganti agregat kasar (kerikil) pada campuran beton ringan, di mana agregat kasar yang digunakan dibuat dengan cara mencampurkan fly ash dengan bahan kimia berupa resin sebagai pengikat atau perekatnya, dengan perbandingan antara fly ash (60\%) dan resin (40\%).

Pada umur 28 hari, kuat tekan beton normal didapat nilai 17,76 Mpa, dan setelah dilakukan pencampuran komposisi agregat $60 \%$ fly ash dan $40 \%$ resin didapat kuat tekan 6,85 Mpa, atau mengalami penurunan dari beton normal sebesar 10,92 Mpa (38,55\%). Dari penelitian ini dapat disimpulkan bahwa beton dengan campuran agregat fly ash $60 \%$ dan resin $40 \%$ ini belum dapat digunakan sebagai beton ringan struktural karena hasil kuat tekannya yang rendah dibanding dengan beton normal, sehingga hanya dapat digunakan untuk beton ringan non struktural.

\section{DAFTAR PUSTAKA}

ASTM C 567, Standard Test Method for Determining Density of Structural Lightweight Concrete, Annual Books of ASTM Standards. USA: Association of Standard Testing Materials.

Eko Hindaryanto Nugroho. (2010). Analisis Porositas dan Permeabilitas Beton dengan Bahan Tambah Fly Ash untuk Perkerasan Kaku (Rigid Pavement), UNS Press, Surakarta. 
K George1 and P Revathi2 (2020), Production and Utilisation of Artificial Coarse Aggregate in Concrete - a Review, Jurnal IOP Conference Series: Materials Science and Engineering.

Purwanto, H., \& Wardani, U. C. (2020). Pengaruh Penambahan Serbuk Besi Terhadap Kuat Tekan Beton Mutu K225. Jurnal Deformasi, 5(2), 103-112.

SNI 03-2461 (2002). Spesifikasi Agregat Ringan Untuk Beton Ringan Struktural. Badan Standarisasi Nasional. Jakarta.

SNI 7656-2012. (2012). Tata Cara Pemilihan Campuran Untuk Beton Normal, Beton Berat dan Beton Massa. Badan Standarisasi Nasional. Jakarta.

SNI 2847 (2013). Tata Cara Struktur Beton Untuk Bangunan Gedung. Badan Standarisasi Nasional. Jakarta.

Tjokrodimuljo, Kardiyono. (2007), Teknologi Beton, Teknik Sipil dan Lingkungan, Universitas Gadjah Mada, Yogyakarta. 